\title{
Arterial hyperoxia and mortality in critically ill patients: a systematic review and meta-analysis
}

\author{
Elisa Damiani ${ }^{1}$, Erica Adrario ${ }^{1}$, Massimo Girardis$^{2}$, Rocco Romano ${ }^{1}$, Paolo Pelaia $^{1}$, Mervyn Singer ${ }^{3}$ \\ and Abele Donati ${ }^{*}$
}

\begin{abstract}
Introduction: The safety of arterial hyperoxia is under increasing scrutiny. We performed a systematic review of the literature to determine whether any association exists between arterial hyperoxia and mortality in critically ill patient subsets.

Methods: Medline, Thomson Reuters Web of Science and Scopus databases were searched from inception to June 2014. Observational or interventional studies evaluating the relationship between hyperoxia (defined as a supranormal arterial $\mathrm{O}_{2}$ tension) and mortality in adult intensive care unit (ICU) patients were included. Studies primarily involving patients with exacerbations of chronic pulmonary disease, acute lung injury and perioperative administration were excluded. Adjusted odds ratio (OR) of patients exposed versus those not exposed to hyperoxia were extracted, if available. Alternatively, unadjusted outcome data were recorded. Data on patients, study characteristics and the criteria used for defining hyperoxia exposure were also extracted. Random-effects models were used for quantitative synthesis of the data, with a primary outcome of hospital mortality.

Results: In total 17 studies (16 observational, 1 prospective before-after) were identified in different patient categories: mechanically ventilated ICU (number of studies $(k)=4$, number of participants $(n)=189,143)$, post-cardiac arrest $(k=6$, $n=19,144)$, stroke $(k=2, n=5,537)$, and traumatic brain injury $(k=5, n=7,488)$. Different criteria were used to define hyperoxia in terms of $\mathrm{PaO}_{2}$ value (first, highest, worst, mean), time of assessment and predetermined cutoffs. Data from studies on ICU patients were not pooled because of extreme heterogeneity (inconsistency $\left(I^{2}\right) 96.73 \%$ ). Hyperoxia was associated with increased mortality in post-cardiac arrest patients $\left(\mathrm{OR}=1.42(1.04\right.$ to 1.92$\left.) \mathrm{I}^{2} 67.73 \%\right)$ stroke $(\mathrm{OR}=1.23$ $(1.06$ to 1.43$\left.) I^{2} 0 \%\right)$ and traumatic brain injury $\left(\mathrm{OR}=1.41(1.03\right.$ to 1.94$\left.) I^{2} 64.54 \%\right)$. However, these results are limited by significant heterogeneity between studies.
\end{abstract}

Conclusions: Hyperoxia may be associated with increased mortality in patients with stroke, traumatic brain injury and those resuscitated from cardiac arrest. However, these results are limited by the high heterogeneity of the included studies.

\section{Introduction}

Oxygen $\left(\mathrm{O}_{2}\right)$ administration is the most widely prescribed therapy in critically ill patients and frequently represents a life-saving intervention. Since hypoxemia is generally viewed as deleterious and moderate levels of arterial hyperoxia as benign, health care practitioners are more likely to accept supranormal arterial $\mathrm{O}_{2}$ levels as this provides a wider safety buffer $[1,2]$.

\footnotetext{
* Correspondence: a.donati@univpm.it

${ }^{1}$ Anaesthesia and Intensive Care Unit, Department of Biomedical Sciences and Public Health, Università Politecnica delle Marche, via Tronto 10, 60126 Torrette di Ancona, Italy

Full list of author information is available at the end of the article
}

The use of supplemental $\mathrm{O}_{2}$ in various medical emergencies is supported by many guidelines [3-5]. One hundred percent $\mathrm{O}_{2}$ is commonly administered during cardiopulmonary resuscitation from cardiac arrest [6]. Normobaric hyperoxia is touted as a potential therapeutic strategy for patients with traumatic brain injury or stroke [7], with an underlying rationale of increased brain $\mathrm{O}_{2}$ delivery [8] and protection of the ischemic penumbra through inducing redistribution of blood from normal to ischemic areas [9]. However, these potential benefits must be weighed against the injurious effects of high-dose supplemental $\mathrm{O}_{2}$. In both animal and human studies there are reports of pulmonary

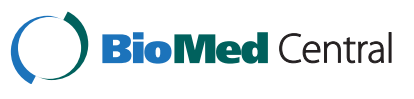

(c) 2014 Damiani et al.; licensee BioMed Central. This is an Open Access article distributed under the terms of the Creative Commons Attribution License (http://creativecommons.org/licenses/by/4.0), which permits unrestricted use, distribution, and reproduction in any medium, provided the original work is properly credited. The Creative Commons Public Domain Dedication waiver (http://creativecommons.org/publicdomain/zero/1.0/) applies to the data made available in this article, unless otherwise stated. 
toxicity [10-12], increased vasoconstriction with a fall in cardiac output [13], free radical-mediated damage to various organs [14], and a marked reduction in coronary blood flow and myocardial $\mathrm{O}_{2}$ consumption [15].

Clinical data regarding the relationship between arterial hyperoxia and outcome are contradictory. An association between arterial hyperoxia and mortality has been reported in disparate patient populations (mechanically ventilated [16], post-cardiac arrest [17], traumatic brain injury [18], stroke [19]) but not confirmed by other studies [20-23]. Therefore, the question whether exposure to supranormal arterial $\mathrm{O}_{2}$ tensions $\left(\mathrm{PaO}_{2}\right)$ is safe in critically ill patients remains unanswered. We thus performed a systematic review and meta-analysis of studies describing the relationship between arterial hyperoxia and mortality in critically ill patients.

\section{Materials and methods}

This report adheres to the Preferred Reporting Items for Systematic reviews and Meta-Analysis (PRISMA) standards for reporting systematic review and meta-analysis studies [24].

\section{Eligibility criteria}

Observational (prospective or retrospective cohort or case-control studies) or randomized controlled trials (RCTs) investigating the relationship between arterial hyperoxia and mortality in critically ill patients were eligible for inclusion. Participants were required to be adult patients admitted to a critical care unit for any reason. We excluded studies involving patients with an acute exacerbation of chronic obstructive pulmonary disease (COPD) or acute lung injury (ALI). As hypoxemia is the main problem in these patients, studies on the impact of hyperoxemia were likely to be uncommon. We expected that studies on patients with COPD/ALI may have explored the effects of excessive $\mathrm{O}_{2}$ flow rather than those of arterial hyperoxemia. In addition, in these patients the $\mathrm{PaO}_{2}$ range defined as normal/acceptable could have been lower than that applied in patients with preserved respiratory function. Studies on surgical patients were excluded unless they were exposed to hyperoxia during a post-operative admission to a critical care unit. Hyperoxia was defined by the measurement of supranormal values of arterial partial $\mathrm{O}_{2}$ pressure $\left(\mathrm{PaO}_{2}\right)$. For defining a condition of exposure to hyperoxia, any cutoff value of $\mathrm{PaO}_{2}$ and time of assessment were deemed acceptable. Studies where patients were defined as 'hyperoxic' solely on the basis of exposure to a predetermined increase in inspired $\mathrm{O}_{2}$ fraction $\left(\mathrm{FiO}_{2}\right)$ were excluded if not guided by any assessment of $\mathrm{PaO}_{2}$. Patients not exposed to hyperoxia constituted the comparator group. The primary outcome of interest was hospital mortality from any cause.

\section{Search strategy}

Studies were identified by searching Medline (PubMed), Scopus and Thomson Reuters Web of Science databases from their inception. The main search was run on 28 March 2014 and updated weekly until June 2014. The keywords 'hyperoxia', 'hyperoxemia', 'arterial oxygen', 'oxygen saturation', 'critically ill', 'acutely ill', 'intensive care', 'critical care', 'mechanically ventilated', 'cardiac arrest', 'cardiopulmonary resuscitation', 'traumatic brain injury', 'head trauma', 'stroke', 'sepsis', 'septic shock', 'trauma', 'post-operative', 'post-surgery', 'cardiac failure', 'heart failure', 'myocardial infarction', 'shock', 'mortality', 'survival', 'death', 'outcome' were typed in various combinations using Boolean operators. Queries were limited to those involving human subjects. The detailed search strategy applied to Medline (PubMed), and adapted for the other databases, is described in Additional file 1 . Hand searches of reference lists of articles and relevant literature reviews were used to complement the computer search. Content pages of the main critical care medicine journals were handsearched to find any relevant in-press articles. The search was not limited by language, but focused solely on articles published in peer-reviewed journals to enhance the methodological rigor of the studies examined and the conclusions drawn.

\section{Study selection}

Two independent reviewers (ED and EA) screened all identified records (title and abstract) and performed the eligibility assessment of the selected full-text articles in an unblinded standardized manner. Disagreements were resolved through discussion or arbitration by a third reviewer $(\mathrm{AD})$. Interobserver agreement was assessed by kappa statistics.

\section{Data extraction}

Two independent investigators (ED and EA) extracted descriptive, methodological and outcome data from all eligible studies using a predefined data extraction form. Disagreements were resolved through consensus. The datasheet included study design (RCT, retrospective or prospective observational study, multicenter or singlecenter), country, years of enrollment, publication year, primary endpoint, sample size, mean age (as a continuous variable), gender distribution (as a percentage of males), category of critical illness (mechanically ventilated, post-cardiac arrest, traumatic brain injury, stroke, other), criteria for the definition of hyperoxia exposure (time of assessment, selection of the first/highest/worst/ mean $\mathrm{PaO}_{2}$, cutoff value to define hyperoxia), prevalence of hyperoxia, overall in-hospital mortality, and prevalence of chronic cardiovascular and/or respiratory disease. Additional data were extracted for studies on post-cardiac arrest patients: average delay to return of spontaneous 
circulation (minutes); prevalence of initial shockable rhythm (ventricular tachycardia/fibrillation); prevalence of out-of-hospital cardiac arrest; prevalence of therapeutic hypothermia. Unadjusted outcome data (number of survivors and nonsurvivors to hospital discharge in hyperoxic and nonhyperoxic patients) and adjusted odds ratio (OR) (95\% confidence interval) describing the association between hyperoxia exposure and mortality were extracted for calculation of effect size (ES). In-hospital mortality was chosen as the primary endpoint of our analysis since it was the outcome measure most frequently reported. When in-hospital mortality was not stated, we extracted data reporting the longest-term mortality available. The study authors were contacted to request additional information whenever a study did not report data necessary for calculation of the ES.

\section{Study quality assessment}

The Newcastle-Ottawa Scale (NOS) for cohort studies was used to assess the quality of the included studies [25]. The item 'representativeness of the exposed cohort' was fulfilled if $\leq 10 \%$ of patients had been excluded because of missing data. The item 'completeness of followup' was fulfilled if $\leq 10 \%$ of patients had been excluded because of missing mortality data. For assessment of comparability of cohorts, two confounding factors were defined a priori: illness severity (as defined by any of the following severity scores: Acute Physiology and Chronic Health Evaluation (APACHE), Simplified Acute Physiology Score (SAPS), Sequential Organ Failure Assessment (SOFA), Injury Severity Score (ISS)) and $\mathrm{FiO}_{2}$. A study was considered to adequately control for each of these factors if it either demonstrated balance between groups for the confounder, or adjusted for it in the statistical analysis.

\section{Statistical analysis}

Data were synthesized using meta-analytic methods $[26,27]$, and statistically pooled by the standard metaanalysis approach, that is studies were weighted by the inverse of the sampling variance. Whenever possible, calculation of the ES of individual studies was based on the adjusted OR of the association between hyperoxia exposure and mortality as compared to nonexposure. When the authors reported results from more than one multivariate model, we extracted data deriving from either the model that included the maximum number of covariates, or the model that included severity of illness and $\mathrm{FiO}_{2}$. If the authors analyzed the unadjusted or adjusted association between mortality and increasing quartiles/quintiles/deciles of $\mathrm{PaO}_{2}$, we considered patients as 'hyperoxic' if they fell in the upper stratum. When adjusted data were not reported or $\mathrm{PaO}_{2}$ was analyzed as a continuous variable, unadjusted ORs were reconstructed from binary raw data (number of survivors/nonsurvivors in hyperoxia exposed/not exposed). When normoxia and hypoxemia were considered as two separate categories, only normoxic patients were included in the comparator group. Overall ES was expressed as OR and its corresponding 95\% confidence interval (CI). The DerSimonian and Laird random effects model was used as a conservative approach to account for different sources of variation among studies. Forest plots were constructed to graphically represent the results. Q statistics were used to assess heterogeneity among studies. A significant $Q$ value indicates a lack of homogeneity of findings among studies [26,27]. Inconsistency analysis $\left(I^{2}\right)$ statistics were then used to quantify the proportion of observed inconsistency across study results not explained by chance [28]. $\mathrm{I}^{2}$ values of $<25 \%, 50 \%$ and $>75 \%$ represent low, moderate and high inconsistency, respectively [28]. Sensitivity analyses were planned a priori to assess the impact of potential outliers (based on statistical significance of the standardized residuals) and sources of heterogeneity. Several variables were identified and their effects on outcome examined. Categorical variables were treated as moderators and the strength of the association between hyperoxia and mortality assessed and compared across subgroups formed by these moderators. Continuous variables were examined as covariates using random effects meta-regression. Meta-regression was performed to assess the effect of study quality (NOS score) on the calculated estimate. The presence of publication bias was investigated through funnel plots both visually and formally by trim and fill analysis and Eggers's linear regression method [29]. A $P$ value less than 0.05 was used to indicate statistical significance. All analyses were conducted using a computer software package (ProMeta Version 2, Internovi, Cesena FC, Italy).

\section{Results}

From the 2,389 articles that were initially identified (Figure 1), 70 potentially relevant original articles were examined in full text ( $\kappa=0.87$ (95\% CI, 0.85 to 0.90$)$ ). Seventeen studies eventually met our inclusion criteria $(\kappa=0.91(0.88$ to 0.94$))$. The study by Kilgannon et al. [30] was excluded as it was a subgroup analysis of the same patient population previously described by the same group [17]. For the study by Ihle et al. [31] we extrapolated outcome data related to the years 2010 to 2011, as the authors used the same database as Bellomo et al. [21] with study populations overlapping for the years 2007 to 2009. Two studies were identified in which hyperoxia exposure was defined on the basis of a peripheral $\mathrm{O}_{2}$ saturation $\left(\mathrm{SpO}_{2}\right)>98 \%$ [2,32]; although it is questionable whether these patients were really hyperoxic to a significant degree, we decided to include these studies in the 


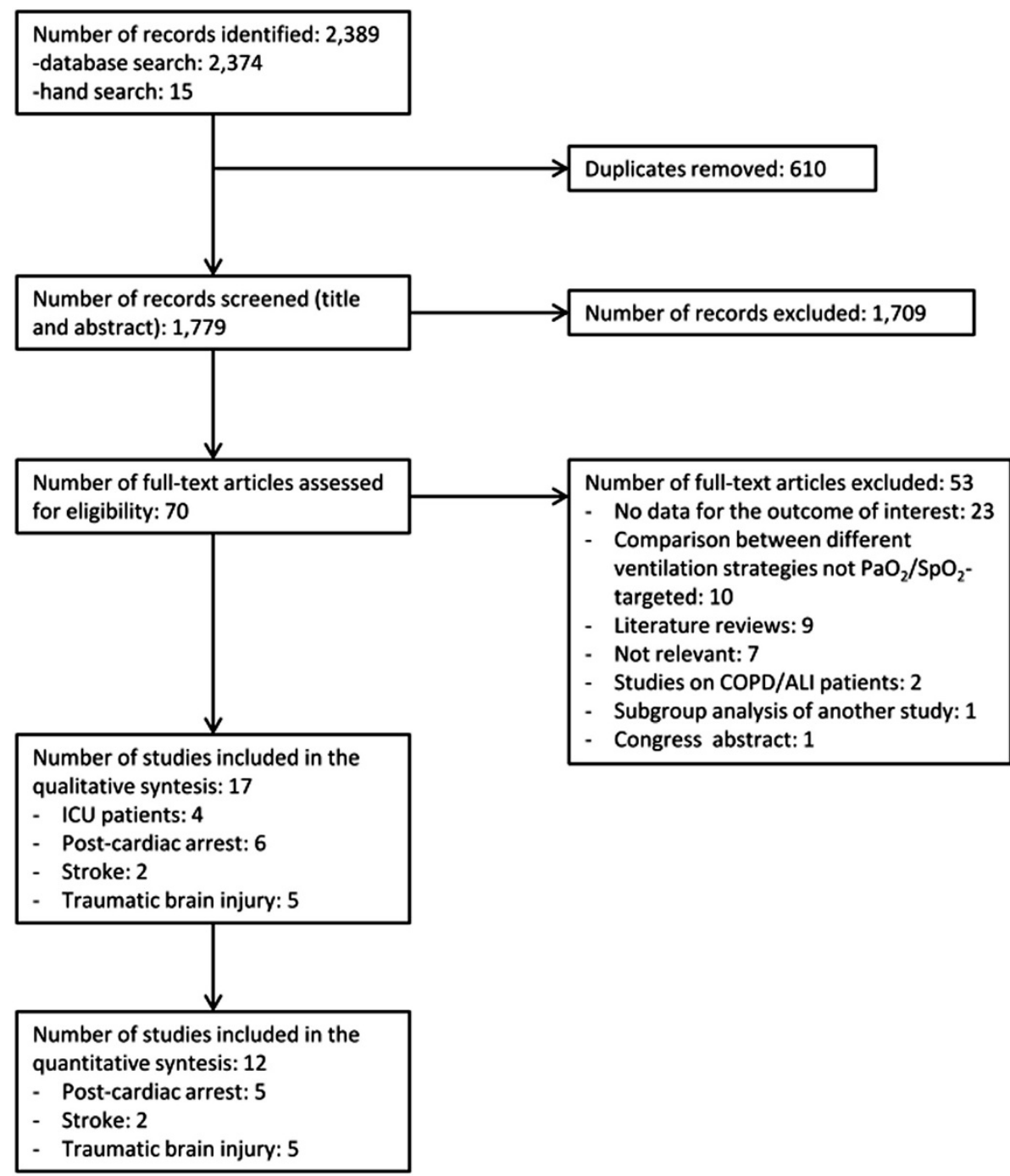

Figure 1 Flow chart representing the selection process of the studies included in the qualitative and quantitative syntheses.

analysis as the reported time-weighted $\mathrm{PaO}_{2}$ values were above the upper normal limit of $100 \mathrm{mmHg}$ in both cases [2,32].

The 17 studies identified were all published in English between 2008 and 2014 and involved different categories of critically ill patients [2,16-23,31-38]. Only four studies (24\%) involved general populations of mechanically ventilated intensive care unit (ICU) patients [2,16,20,32]. Six studies focused upon patients resuscitated from cardiac arrest [17,21,31,35-37], five studies evaluated patients with traumatic brain injury $[18,22,33,34,38]$, while two studies involved patients with stroke $[19,23]$. The main characteristics of the studies are reported in Table 1. Individual unadjusted/adjusted outcome data and variables included in the multivariable models are reported in Table 2. Study quality assessment is reported in Additional file 2.

\section{Mechanically ventilated ICU patients}

The four studies including general populations of mechanically ventilated ICU patients (number of participants $(\mathrm{n})=189,143$ ) were highly heterogeneous in terms of design, outcome measure, criteria for defining hyperoxia exposure, and statistical method applied for analysis (Table 1). de Jonge et al. [16] defined the worst $\mathrm{PaO}_{2}$ as the one associated with the lowest $\mathrm{PaO}_{2} / \mathrm{FiO}_{2}$. Conversely, Eastwood et al. [20] defined the worst $\mathrm{PaO}_{2}$ in patients with an $\mathrm{FiO}_{2} \geq 0.5$ as that associated with the ABG providing the highest arterial-alveolar (A-a) gradient; for patients with an $\mathrm{FiO}_{2}<0.5$, the lowest $\mathrm{PaO}_{2}$ was recorded. If arterial blood gases (ABGs) were taken in patients in whom $\mathrm{FiO}_{2}<0.5$ and $\geq 0.5$ were both recorded during the first 24 hours, the value of $\mathrm{PaO}_{2}$ taken when the $\mathrm{FiO}_{2} \geq 0.5$ was used. In one study [2] hyperoxia was defined on the basis of a time-weighted $\mathrm{SpO}_{2}>98 \%$; 
Table 1 Characteristics of the included studies

\begin{tabular}{|c|c|c|c|c|c|c|c|}
\hline \multirow[t]{2}{*}{ Study } & \multirow[t]{2}{*}{ Design } & \multirow[t]{2}{*}{ Country } & \multicolumn{3}{|c|}{ Hyperoxia, definition } & \multirow[t]{2}{*}{ Comparator group } & \multirow{2}{*}{$\begin{array}{l}\text { Outcome } \\
\text { measure } \\
\text { reported }\end{array}$} \\
\hline & & & $\mathrm{PaO}_{2} / \mathrm{ABG}$ & Time of assessment & Cutoff value & & \\
\hline \multicolumn{8}{|c|}{ Mechanically ventilated ICU patients } \\
\hline de Jonge et al. 2008 [16] & Retrospective cohort, multicenter & Netherlands & Worst $\mathrm{PaO}_{2}$ & First 24 hours & $\geq 120$ mmHg (upper quintile) & $\mathrm{PaO}_{2}$ between 66 and $80 \mathrm{mmHg}$ & $\begin{array}{l}\text { In-hospital } \\
\text { mortality }\end{array}$ \\
\hline Eastwood et al. 2012 [20] & Retrospective cohort, multicenter & $\begin{array}{l}\text { Australia, New } \\
\text { Zealand }\end{array}$ & Worst $\mathrm{PaO}_{2}$ & First 24 hours & $\begin{array}{l}>120 \mathrm{mmHg} \text { for unadjusted } \\
\text { analysis; } \geq 305 \mathrm{mmHg} \\
\text { (upper decile) for adjusted } \\
\text { analysis }\end{array}$ & $\begin{array}{l}\mathrm{PaO}_{2}<120 \mathrm{mmHg} \text { for unadjusted } \\
\text { analysis; } \mathrm{PaO}_{2} \text { between } 75 \text { and } \\
85 \mathrm{mmHg} \text { for adjusted analysis }\end{array}$ & $\begin{array}{l}\text { In-hospital } \\
\text { mortality }\end{array}$ \\
\hline Suzuki et al. 2013 [2] & $\begin{array}{l}\text { Prospective observational } \\
\text { cohort, single-center }\end{array}$ & Australia & $\begin{array}{l}\text { Time-weighted } \\
\mathrm{SpO}_{2}\end{array}$ & $\begin{array}{l}\text { Whole period of mechanical } \\
\text { ventilation }\end{array}$ & Time-weighted $\mathrm{SpO}_{2}>98 \%$ & Not exposed to hyperoxia & $\begin{array}{l}\text { In-hospital } \\
\text { mortality }\end{array}$ \\
\hline Suzuki et al. 2014 [32] & $\begin{array}{l}\text { Prospective before-after, } \\
\text { single-center }\end{array}$ & Australia & $\begin{array}{l}\text { Conventional perio } \\
\text { attending physicia }\end{array}$ & xygenation goals at the discreti & ion of the & $\begin{array}{l}\text { Conservative period: } \mathrm{SpO}_{2} \\
\text { between } 90 \text { and } 92 \%\end{array}$ & $\begin{array}{l}\text { 28-day } \\
\text { mortality }\end{array}$ \\
\hline \multicolumn{8}{|c|}{ Post-cardiac arrest patients } \\
\hline Bellomo et al. 2011 [21] & Retrospective cohort, multicenter & $\begin{array}{l}\text { Australia, New } \\
\text { Zealand }\end{array}$ & Worst $\mathrm{PaO}_{2}$ & First 24 hours & $\geq 300 \mathrm{mmHg}$ & Normoxia & $\begin{array}{l}\text { In-hospital } \\
\text { mortality }\end{array}$ \\
\hline Ihle et al. 2013 [31] & Retrospective cohort, multicenter & Australia & Worst $\mathrm{PaO}_{2}$ & First 24 hours & $\geq 300 \mathrm{mmHg}$ & Normoxia & $\begin{array}{l}\text { In-hospital } \\
\text { mortality }\end{array}$ \\
\hline Janz et al. 2012 [35] & $\begin{array}{l}\text { Retrospective analysis of a } \\
\text { prospective cohort study, } \\
\text { single-center }\end{array}$ & USA & Highest $\mathrm{PaO}_{2}$ & First 24 hours & $\geq 300 \mathrm{mmHg}^{\mathrm{a}}$ & Not exposed to hyperoxia & $\begin{array}{l}\text { In-hospital } \\
\text { mortality }\end{array}$ \\
\hline Kilgannon et al. 2010 [17] & Retrospective cohort, multicenter & USA & First $\mathrm{PaO}_{2}$ & First 24 hours & $\geq 300 \mathrm{mmHg}$ & Not exposed to hyperoxia & $\begin{array}{l}\text { In-hospital } \\
\text { mortality }\end{array}$ \\
\hline Lee et al. 2014 [36] & $\begin{array}{l}\text { Retrospective cohort, single- } \\
\text { center }\end{array}$ & Korea & Mean $\mathrm{PaO}_{2}$ & $\begin{array}{l}\text { From return of spontaneous } \\
\text { circulation to the end of } \\
\text { therapeutic hypothermia }\end{array}$ & $\begin{array}{l}\geq 156.7 \mathrm{mmHg} \text { (upper } \\
\text { quartile) }\end{array}$ & $\begin{array}{l}\mathrm{PaO}_{2} \text { between } 116 \text { and } \\
134.9 \mathrm{mmHg} \text { (second } \\
\text { quartile) }\end{array}$ & $\begin{array}{l}\text { In-hospital } \\
\text { mortality }\end{array}$ \\
\hline Nelskyla et al. 2013 [37] & $\begin{array}{l}\text { Retrospective analysis of a } \\
\text { prospective cohort study, } \\
\text { single-center }\end{array}$ & Australia & Highest $\mathrm{PaO}_{2}$ & First 24 hours & $\geq 300 \mathrm{mmHg}$ & Not exposed to hyperoxia & $\begin{array}{l}\text { In-hospital } \\
\text { mortality }\end{array}$ \\
\hline \multicolumn{8}{|l|}{ Stroke patients } \\
\hline Rincon (a) et al. 2014 [19] & Retrospective cohort, multicenter & USA & First $\mathrm{PaO}_{2}$ & First 24 hours & $\geq 300 \mathrm{mmHg}$ & Normoxia & $\begin{array}{l}\text { In-hospital } \\
\text { mortality }\end{array}$ \\
\hline Young et al. 2012 [23] & Retrospective cohort, multicenter & $\begin{array}{l}\text { Australia and } \\
\text { New Zealand }\end{array}$ & Worst $\mathrm{PaO}_{2}$ & First 24 hours & >341 mmHg (upper decile) & $\begin{array}{l}\text { Normoxia }\left(\mathrm{PaO}_{2}>69\right. \\
\text { and }<341 \mathrm{mmHg}, 2 \mathrm{nd} \\
\text { to 9th deciles) }\end{array}$ & $\begin{array}{l}\text { In-hospital } \\
\text { mortality }\end{array}$ \\
\hline \multicolumn{8}{|l|}{ Traumatic brain injury } \\
\hline Asher et al. 2013 [33] & $\begin{array}{l}\text { Retrospective cohort, single- } \\
\text { center }\end{array}$ & USA & Highest $\mathrm{PaO}_{2}$ & First 72 hours & $\geq 200 \mathrm{mmHg}$ & Not exposed to hyperoxia & $\begin{array}{l}\text { In-hospital } \\
\text { mortality }\end{array}$ \\
\hline Brenner et al. 2012 [18] & Retrospective cohort, multicenter & USA & Mean $\mathrm{PaO}_{2}$ & First 24 hours & $>200 \mathrm{mmHg}$ & Normoxia & $\begin{array}{l}\text { In-hospital } \\
\text { mortality }\end{array}$ \\
\hline
\end{tabular}


Table 1 Characteristics of the included studies (Continued)

\begin{tabular}{|c|c|c|c|c|c|c|c|}
\hline Davis et al. 2009 [34] & $\begin{array}{l}\text { Retrospective cohort, } \\
\text { multicenter }\end{array}$ & USA & First $\mathrm{PaO}_{2}$ & On arrival & $>487$ mmHg & Not exposed to hyperoxia & $\begin{array}{l}\text { In-hospital } \\
\text { mortality }\end{array}$ \\
\hline Raj et al. 2013 [22] & $\begin{array}{l}\text { Retrospective cohort, } \\
\text { multicenter }\end{array}$ & Finland & Worst $\mathrm{PaO}_{2}$ & First 24 hours & $>100$ mmHg & Normoxia & $\begin{array}{l}\text { In-hospital } \\
\text { mortality }\end{array}$ \\
\hline $\begin{array}{l}\text { Rincon (b) et al. } 2014 \\
\text { [38] }\end{array}$ & $\begin{array}{l}\text { Retrospective cohort } \\
\text { multicenter }\end{array}$ & USA & First $\mathrm{PaO}_{2}$ & First 24 hours & $\geq 300 \mathrm{mmHg}$ & Normoxia & $\begin{array}{l}\text { In-hospital } \\
\text { mortality }\end{array}$ \\
\hline
\end{tabular}

${ }^{\mathrm{a} C u t o f f}$ used by the reviewers for the analysis. $\mathrm{PaO}_{2}$. arterial partial oxygen pressure; $\mathrm{ABG}$, arterial blood gas; $\mathrm{ICU}$, intensive care unit; $\mathrm{SpO}_{2}$, peripheral oxygen saturation 
Table 2 Unadjusted and adjusted outcome data extracted for the included studies

\begin{tabular}{|c|c|c|c|c|c|c|}
\hline & \multicolumn{3}{|c|}{ Unadjusted data } & \multicolumn{3}{|l|}{ Adjusted data } \\
\hline & Hyperoxia & Not exposed to hyperoxia & Normoxia & OR $[95 \% \mathrm{Cl}]^{\mathrm{a}}$ & Comparator group & Variables in the model \\
\hline \multicolumn{7}{|l|}{ ICU patients } \\
\hline de Jonge et al. 2008 [16] & NA & NA & NA & 1.23 [1.13-1.34] (upper quintile) & $\mathrm{PaO}_{2} 66-80 \mathrm{mmHg}$ & $\begin{array}{l}\text { Age, SAPS II, GCS < 15, admission type, individual } \\
\text { hospital }\end{array}$ \\
\hline Eastwood et al. 2012 [20] & $58,855 / 17,225^{b}$ & $54,406 / 22,164$ & NA & 0.73 [0.68-0.78] (upper decile) & $\mathrm{PaO}_{2} 75-85 \mathrm{mmHg}$ & $\begin{array}{l}\text { Site, APACHE III risk of death }\left(\mathrm{O}_{2} \text { component }\right. \\
\text { removed), } \mathrm{FiO}_{2} \text {, year }\end{array}$ \\
\hline Suzuki et al. 2013 [2] & $21 / 11$ & $13 / 6$ & NA & NA & & \\
\hline Suzuki et al. 2014 [32] & $35 / 16$ & $45 / 9$ & NA & $0.35[0.12-1.06]$ & Conservative group & $\begin{array}{l}\text { APACHE III score, primary diagnosis, reason for } \\
\text { mechanical ventilation }\end{array}$ \\
\hline \multicolumn{7}{|l|}{ Post-cardiac arrest } \\
\hline Bellomo et al. 2011 [21] & $531 / 754$ & $4,609 / 6,214$ & $1,008 / 911$ & $1.2[1.0-1.5]$ & Normoxia & $\begin{array}{l}\text { APACHE III risk of death }\left(\mathrm{O}_{2} \text { component removed), }\right. \\
\text { treatment limitation, year of admission, lowest } \\
\text { glucose in the first } 24 \text { h, hospital admission from } \\
\text { home, hypoxia/poor } \mathrm{O}_{2} \text { exchange }\end{array}$ \\
\hline Ihle et al. $2013[31]^{c}$ & $11 / 7$ & $137 / 78$ & $129 / 60$ & NA & & \\
\hline Janz et al. $2012[35]^{c}$ & $15 / 31$ & $66 / 62$ & NA & $1.44[1.03-2.02]^{d}$ & Not defined & $\begin{array}{l}\text { Age, time to return of spontaneous circulation, } \\
\text { presence of shock, bystander CPR, initial rhythm }\end{array}$ \\
\hline Kilgannon et al. 2010 [17] & $424 / 732$ & $2,341 / 2,829$ & $639 / 532$ & $1.8[1.5-2.2]$ & Not exposed to hyperoxia & $\begin{array}{l}\text { Age, ED origin, non-independent functional status } \\
\text { at admission, chronic renal failure, active } \\
\text { chemotherapy, high heart rate in ICU, hypotension } \\
\text { at ICU arrival, hypoxia exposure }\end{array}$ \\
\hline Lee et al. $2014[36]^{c}$ & $39 / 14$ & $111 / 49$ & NA & $0.604[0.225-1.621]$ & $\mathrm{PaO}_{2}$ 116.9-134.9 mmHg & $\begin{array}{l}\text { Age, witness of collapse, hypertension, first } \\
\text { monitored rhythm, etiology of cardiac arrest, } \\
\text { time to return of spontaneous circulation, time } \\
\text { from initiation of therapeutic hypothermia to } \\
\text { achieve target temperature, SOFA score } \\
\text { (respiratory component removed) }\end{array}$ \\
\hline Nelskyla et al. 2013 [37] & $20 / 29$ & $24 / 46$ & NA & NA & & \\
\hline \multicolumn{7}{|l|}{ Stroke } \\
\hline Rincon (a) et al. 2014 [19] & $182 / 268$ & $1,252 / 1,192$ & $582 / 502$ & $1.22[1.04-1.48]$ & Normoxia & $\begin{array}{l}\text { Age, GCS, intracranial hemorrhage diagnosis, } \\
\text { hypothermia at ICU admission, hypotension } \\
\text { or hypertension, organ dysfunctions }\end{array}$ \\
\hline Young et al. 2012 [23] & 101/163 & $1,028 / 1,351$ & $927 / 1,188$ & NA & & \\
\hline \multicolumn{7}{|l|}{ Traumatic brain injury } \\
\hline Asher et al. 2013 [33] & $87 / 45$ & $23 / 38$ & $4 / 10$ & $3.1[0.4-24.4]$ (for survival) & Not exposed to hyperoxia & $\begin{array}{l}\text { Age, sex, ISS, politrauma, hematocrit }>30 \% \text {, any } \\
\mathrm{PaCO}_{2} \geq 35 \mathrm{mmHg} \text {, chest injury, ARDS in the } \\
\text { first } 72 \mathrm{~h}\end{array}$ \\
\hline Brenner et al. 2012 [18] & $459 / 207$ & $651 / 230$ & $587 / 191$ & $1.56[1.18-2.07]$ & Normoxia & $\begin{array}{l}\text { Age, sex, ISS, mechanism of injury, admission GCS, } \\
\text { admission systolic blood pressure }\end{array}$ \\
\hline Davis et al. 2009 [34] & $210 / 129$ & $2,342 / 739$ & $1,602 / 479$ & $2.0[1.4-2.7]$ & Not exposed to hyperoxia & \\
\hline
\end{tabular}


Data are expressed as number of survivors/nonsurvivors, unless stated otherwise. ${ }^{\mathrm{a} A s s o c i a t i o n}$ between hyperoxia exposure and increased mortality, unless otherwise stated; ${ }^{\mathrm{b}} \mathrm{PaO}{ }_{2}>120 \mathrm{mmHg}$ for hyperoxia; ${ }^{\mathrm{C}}$ data requested from the authors; ${ }^{\mathrm{P}} \mathrm{PaO}_{2}$ as continuous variable. OR, odds ratio; Cl, confidence interval; ICU, intensive care unit; NA, not available; SAPS, Simplified Acute Physiology Score; GCS, Glasgow Coma Scale; APACHE, Acute Physiology and Chronic Health Evaluation; $\mathrm{O}_{2}$, oxygen; $\mathrm{FiO}_{2}$, inspired oxygen fraction; CPR, cardiopulmonary resuscitation; ED, Emergency Department; SOFA, Sequential Organ Failure Assessment; ISS, Injury

Severity Score; $\mathrm{PaCO}_{2}$, partial pressure of carbon dioxide; ARDS, acute respiratory distress syndrome; MAP, mean arterial pressure; ICP, intracranial pressure

GCS, age, sex, hypotension, ISS, intubation, penetrating mechanism, head Abbreviated

APACHE II ( $\mathrm{O}_{2}$ component removed), year of admission, emergency operation, intracranial pressure monitoring, controlled hypothermia, platelet count

Rincon (b) et al. 2014 [38] 176/80

$645 / 311$

$316 / 87-1.50[1.02-2.40]$

Not exposed to hyperoxia Age comorbidities, GCS, MAP, anemia, organ dysfunction, gender, non-white race, ED boarder status, ICP monitor, abnormal $\mathrm{pH}$, hospital characteristics 
this parameter was calculated as the mean $\mathrm{SpO}_{2}$ between consecutive time points multiplied by the period of time between these time points, with the sum of such time-weighted values being divided by total time to obtain a time-weighted average. For the before-after study by Suzuki et al. [32], we considered the 'conservative' group as not exposed to arterial hyperoxia and the 'conventional' group as exposed to arterial hyperoxia (showing a time-weighted average $\mathrm{SpO}_{2}$ of 98.4\%).

Extreme heterogeneity was found among the study findings $\left(Q(3)=91.85, P<0.001 ; I^{2}=96.73\right)$, with an ES ranging from 0.73 to 2.86 . Individual ES values $(95 \% \mathrm{CI})$ are shown in Figure 2. A pooled estimate was not calculated in view of the insufficient homogeneity.

\section{Patients resuscitated from cardiac arrest}

Six retrospective cohort studies (three multicenter $[17,21,31]$, three single-center [35-37]) evaluated patients resuscitated from cardiac arrest $(\mathrm{n}=19,144)$. Different $\mathrm{PaO}_{2}$ measures were used to define hyperoxia exposure (Table 1). Most studies used a $\mathrm{PaO}_{2}$ cutoff of $300 \mathrm{mmHg}[17,21,31,37]$. In the study by Janz et al. [35], the relationship between mortality and $\mathrm{PaO}_{2}$ as a continuous variable was evaluated by multivariable regression analysis; to limit heterogeneity in both hyperoxia definition and analysis between this and the other studies, we reconstructed the unadjusted binary OR by stratifying patients between hyperoxic and nonhyperoxic groups based on a 300 $\mathrm{mmHg} \mathrm{PaO}_{2}$ cutoff and extracting the number of survivors/nonsurvivors in the two groups. The study by Lee et al. [36] was not included in the quantitative synthesis because of the substantial differences found in comparison to the other reported studies (different criteria for defining hyperoxia).

The pooled ES shows an association between hyperoxia exposure and increased in-hospital mortality $(\mathrm{OR}=$ 1.42 (95\% CI 1.04 to 1.92 ), $P=0.028$, number of studies

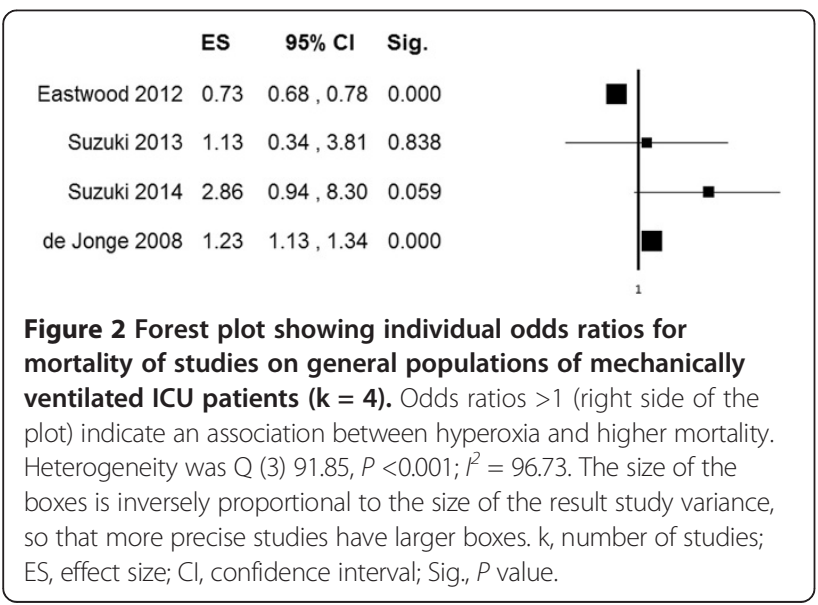

$(\mathrm{k})=5)$, in the presence of a moderately high heterogeneity $\left(Q(4)=12.4, P=0.015 ; I^{2}=67.73\right.$ ) (Figure 3 ). A funnel plot indicates no obvious publication bias (Additional file 3).

Results of the moderator analyses are shown in Table 3. A significant overall ES was found among multicenter $(k=3)$ but not single-center $(k=2)$ studies. A significant association with mortality was indicated only in the study that used the first available $\mathrm{PaO}_{2}$. An association of borderline statistical significance was shown only for studies in which adjusted data were used. Meta-regression analyses showed a progressively weaker association with increasing prevalence of chronic cardiovascular disease ( $\mathrm{k}=4$, range 12 to $36 \%)$. No significant moderator effect was shown by the following variables: mean age ( $k=5$; range 60.5 to 64 years); gender ( $\mathrm{k}=4$; range 54 to $80 \%$ of males); hospital mortality ( $k=5$; range 32.4 to $66 \%$ ); average delay to return of spontaneous circulation ( $\mathrm{k}=3$; range 15 to 25.7 minutes); prevalence of initial shockable rhythm (ventricular tachycardia/fibrillation, $\mathrm{k}=3$; range 40 to $100 \%$ ); prevalence of out-of-hospital cardiac arrest ( $k=5$; range 43 to $100 \%)$. Study quality as defined by the NOS score had no effect on the ES.

\section{Patients with stroke}

Two multicenter retrospective cohort studies $[19,23]$ evaluated the relationship between in-hospital mortality and exposure to arterial hyperoxia in the first 24 hours of ICU admission in patients with stroke $(n=5,537)$. Rincon et al. [19] defined patients with the first $\mathrm{PaO}_{2} \geq 300$ $\mathrm{mmHg}$ as being exposed to hyperoxia. Young et al. [23] evaluated the independent association between mortality and deciles of $\mathrm{PaO}_{2}$, with the upper decile $\left(\mathrm{PaO}_{2}>341\right.$ $\mathrm{mmHg}$ ) used as the reference category. To make the two studies comparable, for [23] we considered patients in the upper decile as those being exposed to hyperoxia and reconstructed the unadjusted OR for mortality; patients in the first decile $\left(\mathrm{PaO}_{2} \leq 69 \mathrm{mmHg}\right)$ were excluded. The pooled ES indicates an association between hyperoxia exposure and increased hospital mortality $(\mathrm{OR}=1.23(95 \%$ CI 1.06 to 1.43$\left.), P=0.005 ; Q(1)=0.04, P=0.844, I^{2}=0\right)$ (Figure 4).

\section{Patients with traumatic brain injury}

Four multicenter $[18,22,34,38]$ and one single-center [33] retrospective cohort studies evaluated patients with traumatic brain injury $(\mathrm{n}=7,488)$. Different criteria were used to define hyperoxia in terms of time of assessment, $\mathrm{PaO}_{2}$ selection and cutoff value used (Table 1). All studies reported the adjusted ORs for hospital mortality (Table 2).

The pooled ES indicates an association between hyperoxia exposure and increased mortality (OR $=1.41$ (95\% CI 1.03 to 1.94$), P=0.032$ ) in the presence of significant 


$$
\begin{array}{rccrl} 
& \text { ES } & \mathbf{9 5 \%} \text { Cl } & \text { W } & \text { Sig. } \\
\text { Bellomo 2011 } & 1.20 & 1.00,1.50 & 33.21 \% & 0.078 \\
\text { Ihle 2013 } & 1.37 & 0.51,3.70 & 7.95 \% & 0.537 \\
\text { Janz 2012 } & 2.20 & 1.08,4.46 & 13.10 \% & 0.029 \\
\text { Kilgannon 2010 } & 1.80 & 1.50,2.20 & 33.71 \% & 0.000 \\
\text { Nelskyla 2013 } & 0.76 & 0.36,1.61 & 12.03 \% & 0.468 \\
\text { Overall (random-effects model) } & 1.42 & 1.04,1.95 & 100.00 \% & 0.028
\end{array}
$$

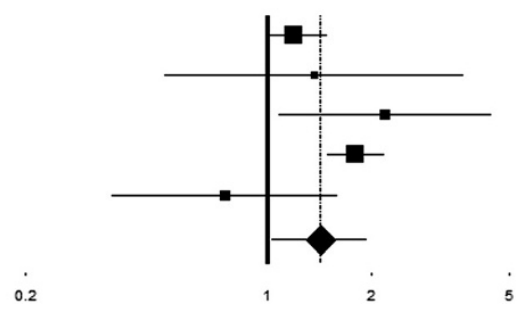

Figure 3 Forest plot showing individual and pooled odds ratios for mortality of studies on patients resuscitated from cardiac arrest. Odds ratios $>1$ (right side of the plot) indicate an association between hyperoxia and higher mortality. Heterogeneity was $Q(4)=12.4, P=0.015$; $P^{2}=67.73$. The size of the boxes is inversely proportional to the size of the result study variance; more precise studies have larger boxes. ES, effect size; Cl, confidence interval; W, weight; Sig., $P$ value.

heterogeneity $\left(Q(4)=11.28, P=0.024 ; I^{2}=64.54\right)$ (Figure 5). The funnel plot indicated no obvious publication bias (Additional file 4). The exclusion of the study by Asher et al. [33] (single-center, time of $\mathrm{PaO}_{2}$ assessment beyond the first 24 hours) in the sensitivity analysis did not substantially change the combined ES $(\mathrm{OR}=1.46$ (95\% CI 1.08 to 1.98$)$ ) nor did it decrease heterogeneity $\left(I^{2}=67.29\right)$. Results of the moderator analyses are shown in Table 4, with studies stratified based on design, $\mathrm{PaO}_{2}$ value and cutoff used for defining hyperoxia, time of $\mathrm{PaO}_{2}$ assessment and comparator group. Study quality as defined by the NOS score, mean age and gender did not influence the ES.

\section{Discussion}

The main findings of our systematic review and metaanalysis may be summarized in three points. First, the majority of studies that explored the relationship between arterial hyperoxia and mortality were retrospective observational investigations, with only one interventional prospective before-after study comparing a conventional ventilation strategy against a more conservative strategy. RCTs comparing two different $\mathrm{PaO}_{2} / \mathrm{SpO}_{2}$-targeted ventilation strategies are lacking. Second, high heterogeneity was found between studies in the criteria used for defining hyperoxia exposure $\left(\mathrm{PaO}_{2}\right.$ value and cutoff selected, time of assessment) and the statistical method applied for analysis; this

Table 3 Moderator analyses for studies on patients resuscitated from cardiac arrest $(\mathbf{k}=5)$

\begin{tabular}{|c|c|c|c|c|c|c|c|}
\hline & $k$ & Effect size (OR) & $95 \% \mathrm{Cl}$ & $P$ & $Q$ & $1^{2}$ & $P^{a}$ \\
\hline Study design & & & & & & & 0.836 \\
\hline Multicenter & 3 & 1.46 & $1.03-2.07$ & 0.031 & $8.15^{*}$ & 75.45 & \\
\hline Single-center & 2 & 1.30 & $0.46-3.70$ & 0.622 & $4.10^{*}$ & 75.60 & \\
\hline Hyperoxia, definition & & & & & & & 0.017 \\
\hline First $\mathrm{PaO}_{2}$ & 1 & 1.80 & $1.50-2.20$ & 0.000 & - & - & \\
\hline Highest $\mathrm{PaO}_{2}$ & 2 & 1.30 & $0.46-3.70$ & 0.622 & $4.10^{*}$ & 75.60 & \\
\hline Worst $\mathrm{PaO}_{2}$ & 2 & 1.21 & $0.99-1.47$ & 0.064 & 0.06 & 0.00 & \\
\hline Comparator group & & & & & & & 0.381 \\
\hline Not exposed to hyperoxia & 3 & 1.54 & $0.93-2.54$ & 0.095 & 5.23 & 61.78 & \\
\hline Normoxia & 2 & 1.21 & $0.99-1.47$ & 0.064 & 0.06 & 0.00 & \\
\hline Outcome data & & & & & & & 0.791 \\
\hline Adjusted & 2 & 1.47 & $0.99-2.19$ & 0.057 & $8.12^{* *}$ & 87.69 & \\
\hline \multirow[t]{2}{*}{ Unadjusted } & 3 & 1.32 & $0.68-2.58$ & 0.409 & 4.10 & 51.21 & \\
\hline & $k$ & Beta & $P$ & & & & \\
\hline \multicolumn{8}{|l|}{ Study quality } \\
\hline NOS score & 5 & -0.24 & 0.184 & & & & \\
\hline \multicolumn{8}{|c|}{ Chronic cardiovascular disease } \\
\hline Percentage & 4 & -0.04 & 0.024 & & & & \\
\hline
\end{tabular}

${ }^{a}$ Analysis of variance Q-test between study subgroups. ${ }^{*} P<0.05 ;{ }^{* *} P<0.01$. $\mathrm{k}$, number of studies; OR, odds ratio; $\mathrm{Cl}$, confidence interval; $\mathrm{Q}$, test for heterogeneity; ${ }^{2}$, inconsistency between studies; $\mathrm{PaO}_{2}$, arterial partial oxygen pressure; Beta, coefficient of the random effects meta-regression analysis: positive and negative values indicate direct and inverse relationships, respectively; NOS Newcastle-Ottawa Scale. 


\section{$\begin{array}{rccccc} & \text { ES } & \mathbf{9 5 \%} \mathrm{Cl} & \mathbf{W} & \text { Sig. } \\ \text { Rincon (a) } 2014 & 1.22 & 1.04,1.48 & 68.91 \% & 0.027 \\ \text { Young 2012 } & 1.26 & 0.97,1.64 & 31.09 \% & 0.085 & \\ \text { Overall (random-effects model) } & 1.23 & 1.06,1.43 & 100.00 \% & 0.005 & \end{array}$}

Figure 4 Forest plot showing individual and pooled odds ratios for mortality of studies on patients with stroke. Odds ratios $>1$ (right side of the plot) indicate an association between hyperoxia and higher mortality. Heterogeneity was $Q(1)=0.04, P=0.844, P^{2}=0$. The size of the boxes is inversely proportional to the size of the result study variance, so that more precise studies have larger boxes. $\mathrm{ES}$, effect size; $\mathrm{Cl}$, confidence interval; W, weight; Sig., $P$ value.

limits comparison between the study results. Third, while studies in general populations of ICU patients gave highly inconsistent results, an association between arterial hyperoxia and increased hospital mortality was found in critically ill patient subsets (post-cardiac arrest, stroke, traumatic brain injury).

Four studies evaluated general populations of mechanically ventilated patients $[2,16,20,32]$ and gave highly inconsistent results. Two large multicenter retrospective studies $[16,20]$ reported a U-shaped relationship between $\mathrm{PaO}_{2}$ levels and mortality by unadjusted analysis. After adjusting for potential confounders including severity of illness, the association between higher $\mathrm{PaO}_{2}$ levels and mortality was confirmed only by de Jonge et al. [16], while Eastwood et al. [20] showed a protective effect of hyperoxia. Differences in the methods applied for the analysis $\left(\mathrm{PaO}_{2}\right.$ stratified in quintiles/deciles, different reference categories) make these studies difficult to compare. A pilot before-after trial was the only interventional study that compared conventional management to a conservative strategy using an $\mathrm{SpO}_{2}$ target between 90 and $92 \%$ [32]. Although this study was underpowered to demonstrate a difference in mortality, it supported the feasibility and safety of a restrictive $\mathrm{O}_{2}$ therapy, which led to a marked reduction in $\mathrm{O}_{2}$ exposure without being associated with major clinical and physiological adverse effects.
Our analysis showed a significant association between hyperoxia exposure and mortality in patients resuscitated from cardiac arrest. This is consistent with the result of a recent meta-analysis by Wang et al. [39]. In a meta-analysis of animal trials, the administration of $100 \% \mathrm{O}_{2}$ therapy following resuscitation from cardiac arrest was associated with worse neurological outcomes as compared with lower $\mathrm{O}_{2}$ concentrations [40]. An association between hyperoxia exposure and poor neurological outcomes has been reported by several authors $[17,35,36,41]$, but not confirmed by a recent multicenter observational study [42] that instead highlighted $\mathrm{PaCO}_{2}$ as a possible confounding factor. The adverse effects of hyperoxia may be due to enhanced oxidative stress, which may be particularly deleterious during the early reperfusion phase after cardiac arrest, and a vasoconstrictor effect that may paradoxically lead to a net reduction in local $\mathrm{O}_{2}$ delivery to tissues including the myocardium and brain [43]. Mechanisms by which hyperoxia causes vasoconstriction include an inhibition of vasodilator (prostaglandins, nitric oxide) by reactive $\mathrm{O}_{2}$ species [43]. Of note, the strength of association between hyperoxia and mortality was inversely related to the prevalence of chronic cardiovascular disease. We speculate that the response to a high $\mathrm{O}_{2}$ tension may be blunted in the presence of an underlying endothelial dysfunction, where nitric oxide levels may be

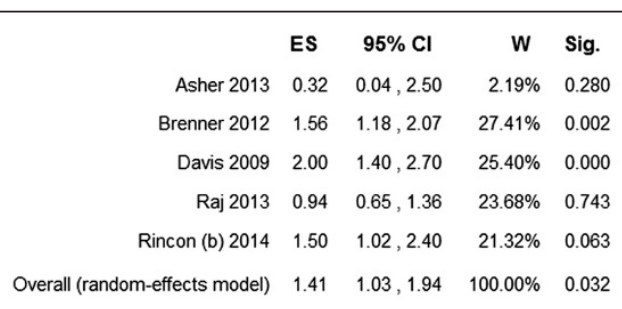

0.01

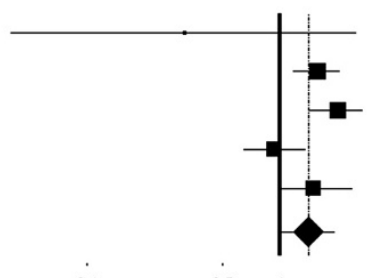

0.1
5

Figure 5 Forest plot showing individual and pooled odds ratio for mortality of studies on patients with traumatic brain injury.

Odds ratios $>1$ (right side of the plot) indicate an association between hyperoxia and higher mortality. Heterogeneity was $Q(4)=11.28, P=0.024$;

$P=64.54$. The size of the boxes is inversely proportional to the size of the result study variance; more precise studies have larger boxes. ES, effect size; $\mathrm{Cl}$, confidence interval; $\mathrm{W}$, weight; Sig., $P$ value. 
Table 4 Moderator analyses for studies in patients with traumatic brain injury $(k=5)$

\begin{tabular}{|c|c|c|c|c|c|c|c|}
\hline & $k$ & Effect size (OR) & $95 \% \mathrm{Cl}$ & $P$ & $Q$ & $I^{2}$ & $P^{\mathrm{a}}$ \\
\hline Study design & & & & & & & 0.154 \\
\hline Multicenter & 4 & 1.46 & $1.08-1.98$ & 0.014 & $9.17^{*}$ & 67.29 & \\
\hline Single-center & 1 & 0.32 & $0.04-2.50$ & 0.280 & - & - & \\
\hline Hyperoxia, definition & & & & & & & 0.019 \\
\hline First $\mathrm{PaO}_{2}$ & 2 & 1.79 & $1.36-2.36$ & 0.000 & 1.09 & 8.51 & \\
\hline Highest $\mathrm{PaO}_{2}$ & 1 & 0.32 & $0.04-2.50$ & 0.280 & - & - & \\
\hline Mean $\mathrm{PaO}_{2}$ & 1 & 1.56 & $1.18-2.07$ & 0.002 & - & - & \\
\hline Worst $\mathrm{PaO}_{2}$ & 1 & 0.94 & $0.65-1.36$ & 0.743 & - & - & \\
\hline Hyperoxia, time of assessment & & & & & & & 0.154 \\
\hline First 24 hours & 4 & 1.46 & $1.08-1.98$ & 0.014 & $9.17^{*}$ & 67.29 & \\
\hline Beyond the first 24 hours & 1 & 0.32 & $0.04-2.50$ & 0.280 & - & - & \\
\hline $\mathrm{PaO}_{2}$ cutoff & & & & & & & 0.126 \\
\hline$<300$ mmHg (moderate hyperoxia) & 3 & 1.14 & $0.68-1.90$ & 0.618 & $6.32^{*}$ & 68.34 & \\
\hline 2300 mmHg (extreme hyperoxia) & 2 & 1.79 & $1.36-2.36$ & 0.000 & 1.09 & 8.51 & \\
\hline Comparator group & & & & & & & 0.824 \\
\hline Not exposed to hyperoxia & 2 & 1.08 & $0.20-5.89$ & 0.933 & 2.94 & 66.03 & \\
\hline \multirow[t]{2}{*}{ Normoxia } & 3 & 1.31 & $0.95-1.81$ & 0.101 & 4.93 & 59.47 & \\
\hline & $k$ & Beta & $P$ & & & & \\
\hline \multicolumn{8}{|l|}{ Study quality } \\
\hline NOS score & 5 & 0.26 & 0.281 & & & & \\
\hline
\end{tabular}

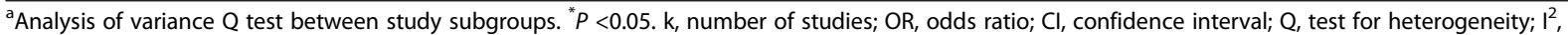
inconsistency between studies; $\mathrm{PaO}_{2}$, arterial partial oxygen pressure; Beta, coefficient of the random effects meta-regression analysis: positive and negative values indicate direct and inverse relationships, respectively; NOS, Newcastle-Ottawa Scale.

chronically low [44]. However, this hypothesis can be challenged by data showing a deleterious effect of high $\mathrm{O}_{2}$ in patients with severe coronary artery disease and myocardial infarction $[45,46]$. An alternative hypothesis may be that hyperoxia exposure had a minor role on mortality when the prevalence of cardiovascular comorbidity was higher.

The exposure to arterial hyperoxia in the first 24 hours of ICU admission was associated with higher mortality in patients with stroke, although this result is limited by the low number of studies included. Previous RCTs showed only transient radiological (magnetic resonance imaging) and clinical improvement [47], no benefit [48] or worse outcomes [49] in stroke patients receiving supplemental $\mathrm{O}_{2}$ during their initial management. The Stroke Oxygen Study RCT, due to report in early 2016, is comparing three-day continuous or nocturnal $\mathrm{O}_{2}$ administration with no supplemental $\mathrm{O}_{2}$ in 6,000 patients (ISRCTN52416964, www.controlled-trials.com). Likewise, arterial hyperoxia was associated with increased hospital mortality in patients with traumatic brain injury. This should, however, be interpreted with caution given the heterogeneous characteristics of the studies included. The rationale for giving high $\mathrm{O}_{2}$ concentrations to patients with traumatic brain injury is to improve brain $\mathrm{O}_{2}$ delivery and metabolism [50]. While studies using indirect measures of brain metabolism provided promising results [7], these were not subsequently confirmed by a study that found no improvement in brain $\mathrm{O}_{2}$ utilization measured by positron emission tomography one hour after ventilation with $100 \% \mathrm{O}_{2}$ [51].

The different criteria used for defining hyperoxia exposure were the main source of heterogeneity among the analyzed studies. The selection of 'worst' $\mathrm{PaO}_{2}$ based on the A-a gradient [20-23,31] has been questioned by several authors, as this gradient does not correlate in a linear fashion with $\mathrm{PaO}_{2}$ as the $\mathrm{FiO}_{2}$ increases [35] and this method may reduce the probability of finding any association between hyperoxia and mortality [52]. However, a subanalysis by Bellomo et al. [21] on a sample of 100 patients showed that the worst $\mathrm{PaO}_{2}$ was more representative of mean $\mathrm{PaO}_{2}$ than was the first $\mathrm{PaO}_{2}$ measured after ICU admission. Different $\mathrm{PaO}_{2}$ measures may have different pathophysiological consequences. If even short periods of hyperoxia were dangerous, then the highest $\mathrm{PaO}_{2}$ would represent the most sensitive approach to identify patients at risk; conversely, if the overall effect depended on the total amount of excess $\mathrm{O}_{2}$ received, then the mean $\mathrm{PaO}_{2}$ or a time-weighted measure would be a better choice. Alternatively, the first 
$\mathrm{PaO}_{2}$ measurement would be preferable if the deleterious effects of hyperoxia were more pronounced in the early phase of the disease. Regardless of disease category, all studies that considered the first available $\mathrm{PaO}_{2}[17,19,38]$ found an independent association between hyperoxia exposure and hospital mortality, while studies using other measures showed more inconsistent results. This may suggest that exposure to high $\mathrm{O}_{2}$ tensions in the early phase of the critical illness may be particularly associated with worse outcomes. Interestingly, in a subgroup analysis by de Jonge et al. [16], exposure to hyperoxia as defined by higher mean $\mathrm{PaO}_{2}$ values during the entire ICU stay was not independently associated with mortality. All studies that considered a timespan longer than the first 24 hours for assessing oxygenation status did not find any significant association between arterial hyperoxia and worse outcomes $[2,33,36]$.

In most of the studies, patients were categorized as hyperoxic or nonhyperoxic based on an arbitrarily predetermined $\mathrm{PaO}_{2}$ cutoff value. Similarly, our analysis was based on binary ORs of hyperoxia exposure versus nonexposure. This approach may be limited by poor resolution in describing the relationship between increasing arterial $\mathrm{O}_{2}$ tensions and outcome. Several studies in which $\mathrm{PaO}_{2}$ was analyzed as a continuous variable showed a linear relationship between increasing arterial $\mathrm{O}_{2}$ tensions and mortality, without a clear threshold for harm $[30,35]$. Furthermore, there is no consensus on the $\mathrm{PaO}_{2}$ cutoff value to use for defining hyperoxia exposure, which varied markedly across the analyzed studies. This is likely to influence the associations observed. In a meta-regression analysis on the overall set of studies, the association between hyperoxia and worse outcome appeared to become stronger when the $\mathrm{PaO}_{2}$ cutoff value used for defining exposure increased (data shown in Additional file 5).

\section{Strengths and weaknesses}

This is the first systematic review on the relationship between arterial hyperoxia and mortality in critically ill patients that gathers together data from a large number of subjects within several distinct disease categories. In our quantitative data syntheses, every effort was made to control for possible sources of heterogeneity and confounding factors. The authors were contacted if additional unpublished data were needed; any overlap between study populations was avoided. Whenever possible, adjusted outcome data were used and/or hypoxic patients excluded. Moderator analyses were performed to analyze the impact of several sources of heterogeneity (definition of hyperoxia exposure, study design). Study quality was assessed by means of a standardized scale and its impact on the studied association was explored. A random-effects model was used to pool data to account for unmeasured confounding factors and sources of heterogeneity.
Our analysis has several limitations. First, the studies were mainly observational investigations that cannot directly support any causal relationship between hyperoxia exposure and worse outcome. Higher $\mathrm{PaO}_{2}$ levels may simply reflect the clinicians' attempts to optimize $\mathrm{O}_{2}$ delivery by administering a higher $\mathrm{FiO}_{2}$; thus $\mathrm{PaO}_{2}$ becomes a marker of illness severity rather than being directly responsible for the outcome. Second, the included studies used different criteria for defining hyperoxia exposure and applied different statistical methods for analysis $\left(\mathrm{PaO}_{2}\right.$ as an ordinal/continuous variable; different multivariable regression models). Third, hypoxemic patients could not always be excluded from the analysis: these patients are likely to be responsible for an increased mortality in the subgroup of those not exposed to hyperoxia and might thus have blunted the studied association. Finally, we did not include unpublished studies, dissertations, or conference abstracts. We decided to consider only published material to ensure that only higher quality, peer-reviewed studies were included in the analysis.

\section{Clinical implications and directions for future research}

Given the widespread use of $\mathrm{O}_{2}$ therapy in critical care, clinicians should be aware of the potentially deleterious effects of excessive $\mathrm{O}_{2}$ administration. Several studies reported that $\mathrm{FiO}_{2}$ is rarely adjusted for arterial hyperoxia, especially when this occurs at lower $\mathrm{FiO}_{2}$ settings $[1,2]$. The rationale for giving supplemental $\mathrm{O}_{2}$ to nonhypoxemic patients should be reconsidered as there is insufficient evidence of benefit [43]. When hemoglobin is fully saturated, additional $\mathrm{O}_{2}$ only marginally increases $\mathrm{O}_{2}$ transport capacity; conversely, a paradoxical decrease in regional $\mathrm{O}_{2}$ delivery could be caused by vasoconstriction [53].

An urgent need exists for adequately designed studies to provide conclusive answers regarding the safety of hyperoxia in critically ill patients. Only RCTs can confirm a causal relationship between hyperoxia exposure and higher mortality. These trials should evaluate ventilation strategies using different $\mathrm{PaO}_{2}$ targets for titrating $\mathrm{FiO}_{2}$, rather than comparing two arbitrarily selected $\mathrm{FiO}_{2}$ targets. A pilot before-after study has supported the safety and feasibility of a conservative oxygen therapy [32]. RCTs comparing current liberal ventilation practices to more restrictive approaches in ICU patients are currently ongoing (ClinicalTrials.gov, NCT01319643 and NCT01722422).

There is an imperative to identify the best criteria that define hyperoxia exposure in observational studies. The relationship between hyperoxia and mortality should be evaluated using different criteria for defining hyperoxia exposure, comparing different $\mathrm{PaO}_{2}$ measures and the time of assessment. This analysis may have important 
pathophysiological implications and could clarify whether early exposure to hyperoxia during critical illness is more deleterious. In future research, it would also be more useful to assess and report the relationship between mortality and $\mathrm{PaO}_{2}$ as a continuous variable, instead of stratifying patients on the basis of an arbitrary $\mathrm{PaO}_{2}$ cutoff value. Finally, further studies should address other specific categories of critically ill patients, such as sepsis, polytrauma, post-operative cases and hemorrhagic shock.

\section{Conclusions}

The majority of studies that have explored the relationship between arterial hyperoxia and mortality in critically ill patients are retrospective observational investigations, with only one prospective before-after study supporting the safety of a more conservative strategy. A quantitative data synthesis was not possible for studies on general populations of mechanically ventilated ICU patients because of differences in design, definition of hyperoxia, and the outcome measure reported. Hyperoxia exposure may be associated with mortality in patient subsets (post-cardiac arrest, stroke and traumatic brain injury). However, these results must be interpreted cautiously given the heterogeneity in criteria used for defining hyperoxia exposure and a significant inconsistency between study findings. Nevertheless, these data provide the rationale for future RCTs comparing conventional practice against more restrictive oxygenation targets.

\section{Key messages}

- There is insufficient evidence regarding the safety of arterial hyperoxia in critically ill patients. Most of the existing studies are observational investigations with highly heterogeneous characteristics and inconsistent results. Randomized controlled trials are lacking.

- Arterial hyperoxia may be associated with higher mortality in some critically ill patient subsets (post-cardiac arrest, stroke and traumatic brain injury).

\section{Additional files}

Additional file 1: Search strategy. Search strategy applied for Medline (PubMed) and adapted for the other electronic databases.

Additional file 2: Study quality assessment with the Newcastle-Ottawa Scale (NOS). Items fulfilled are indicated by an '*'.

Additional file 3: Funnel plot related to the five studies evaluating patients resuscitated from cardiac arrest. Funnel plot analysis did not show any asymmetry.

Additional file 4: Funnel plot related to the five studies evaluating patients with traumatic brain injury. Funnel plot analysis did not show any asymmetry.

Additional file 5: Meta-regression analysis showing the impact on the study ES of the $\mathrm{PaO}_{2}$ cutoff used for defining hyperoxia. Each circle represents a study. The size of the circles is inversely proportional to the size of the result study variance, so that more precise studies have larger circles. Meta-regression analysis showed that the strength of the association between arterial hyperoxia and mortality increased with increasing $\mathrm{PaO}_{2}$ cutoff values used for defining hyperoxia exposure.

\section{Abbreviations}

(A-a): alveolar-arterial; ABG: arterial blood gas; ALI: acute lung injury; APACHE: Acute Physiology and Chronic Health Evaluation; Cl: confidence interval; COPD: chronic obstructive pulmonary disease; ES: effect size; $\mathrm{FiO}_{2}$ : inspired oxygen fraction; $I^{2}$ : inconsistency analysis; ICU: intensive care unit; ISS: Injury Severity Score; k: number of studies; n: number of participants; NOS: Newcastle-Ottawa Scale; $\mathrm{O}_{2}$ : oxygen; OR: odds ratio; $\mathrm{PaO}_{2}$ : arterial partial oxygen pressure; $\mathrm{RCT}$ : randomized controlled trial; SAPS: Simplified Acute Physiology Score; SOFA: Sequential Organ Failure Assessment; $\mathrm{SpO}_{2}$ : peripheral oxygen saturation.

\section{Competing interests}

The authors declare that they have no competing interests.

\section{Authors' contributions}

ED contributed to the study conception and design, acquisition, analysis and interpretation of data, and drafting of the manuscript. EA and AD contributed to the study conception, data acquisition, interpretation of results, and drafting of the manuscript. MG, RR, PP and MS made substantial contributions to both study design and data interpretation plus critical revision of the manuscript. All authors have read and approved the final version of the manuscript. All authors agree to be accountable for all aspects of the work ensuring that questions related to the accuracy or integrity of any part of the work are appropriately investigated and resolved.

\section{Acknowledgements}

We thank the authors Dr JF Ihle, Dr DR Janz, Dr BK Lee and Dr MS Vavilala for kindly answering our queries and providing additional information regarding their studies.

\section{Author details}

${ }^{1}$ Anaesthesia and Intensive Care Unit, Department of Biomedical Sciences and Public Health, Università Politecnica delle Marche, via Tronto 10,60126 Torrette di Ancona, Italy. ${ }^{2}$ Department of Anaesthesia and Intensive Care, University Hospital of Modena, Via del Pozzo 71, 41124 Modena, Italy. ${ }^{3}$ Bloomsbury Institute of Intensive Care Medicine, University College London, Gower Street, London WC1E 6BT, UK.

Received: 11 September 2014 Accepted: 8 December 2014

Published online: 23 December 2014

\section{References}

1. de Graaf AE, Dongelmans DA, Binnekade JM, de Jonge E: Clinicians' response to hyperoxia in ventilated patients in a Dutch ICU depends on the level of $\mathrm{FiO}_{2}$. Intensive Care Med 2011, 37:46-51.

2. Suzuki S, Eastwood GM, Peck L, Glassford NJ, Bellomo R: Current oxygen management in mechanically ventilated patients: a prospective observational cohort study. J Crit Care 2013, 28:647-654

3. Task Force for Diagnosis and Treatment of Acute and Chronic Heart Failure 2008 of European Society of Cardiology, Dickstein K, Cohen-Solal A, Filippatos G, McMurray JJ, Ponikowski P, Poole-Wilson PA, Strömberg A, van Veldhuisen DJ, Atar D, Hoes AW, Keren A, Mebazaa A, Nieminen M, Priori SG, Swedberg K, ESC Committee for Practice Guidelines, Vahanian A, Camm J, De Caterina R, Dean V, Dickstein K, Filippatos G, Funck-Brentano C, Hellemans I, Kristensen SD, McGregor K, Sechtem U, Silber S, Tendera M, et al: ESC guidelines for the diagnosis and treatment of acute and chronic heart failure 2008: the task force for the diagnosis and treatment of acute and chronic heart failure 2008 of the European Society of Cardiology. Developed in collaboration with the heart failure association of the ESC (HFA) and endorsed by the European Society of Intensive Care Medicine (ESICM). Eur Heart J 2008, 29:2388-2442.

4. Anderson JL, Adams CD, Antman EM, Bridges CR, Califf RM, Casey DE Jr, Chavey WE II, Fesmire FM, Hochman JS, Levin TN, Lincoff AM, Peterson ED, Theroux P, Wenger NK, Wright RS, Smith SC Jr, Jacobs AK, Adams CD, 
Anderson JL, Antman EM, Halperin JL, Hunt SA, Krumholz HM, Kushner FG, Lytle BW, Nishimura R, Ornato JP, Page RL, Riegel B, American College of Cardiology, American Heart Association Task Force on Practice Guidelines (Writing Committee to Revise the 2002 Guidelines for the Management of Patients With Unstable Angina/Non-ST-Elevation Myocardial Infarction), American College of Emergency Physicians, Society for Cardiovascular Angiography and Interventions, Society of Thoracic Surgeons, American Association of Cardiovascular and Pulmonary Rehabilitation, Society for Academic Emergency Medicine: ACC/AHA 2007 guidelines for the management of patients with unstable angina/non-ST-elevation myocardial infarction: a report of the American College of Cardiology/ American Heart Association task force on practice guidelines (writing committee to revise the 2002 guidelines for the management of patients with unstable angina/non-ST-elevation myocardial infarction) developed in collaboration with the American College of Emergency Physicians, the Society for Cardiovascular Angiography and Interventions, and the Society of Thoracic Surgeons endorsed by the American Association of Cardiovascular and Pulmonary Rehabilitation and the Society for Academic Emergency Medicine. J Am Coll Cardiol 2007, 50:e1-e157.

5. O'Driscoll R, Davison A, Elliott M, Howard L, Wedzicha J, Mackway-Jones K, Jenkins P, Kishen R, Levy M, Perrott S, Mansfield L, Evans A, Panizzo S, Moore F, Whitmore D, Gibbs S, Martin B, Hinshaw K: BTS guideline for emergency oxygen use in adult patients. Thorax 2008, 63:vi1-68.

6. Peberdy MA, Callaway CW, Neumar RW, Geocadin RG, Zimmerman JL, Donnino M, Gabrielli A, Silvers SM, Zaritsky AL, Merchant R, Vanden Hoek TL, Kronick SL: Part 9: post-cardiac arrest care: 2010 American Heart Association guidelines for cardiopulmonary resuscitation and emergency cardiovascular care. Circulation 2010, 2010:768-786.

7. Kumaria A, Tolias CM: Normobaric hyperoxia therapy for traumatic brain injury and stroke: a review. Br J Neurosurgery 2009, 23:576-584.

8. Menzel M, Doppenberg EM, Zauner A, Soukup J, Reinert MM, Bullock R: Increased inspired oxygen concentration as a factor in improved brain tissue oxygenation and tissue lactate levels after severe human head injury. J Neurosurg 1999, 91:1-10.

9. Singhal AB: Oxygen therapy in stroke: past, present, and future. Int J Stroke 2006, 1:191-200.

10. Fracica PJ, Knapp MJ, Piantadosi CA, Takeda K, Fulkerson WJ, Coleman RE, Wolfe WG, Crapo JD: Responses of baboons to prolonged hyperoxia: physiology and qualitative pathology. J Appl Physiol 1991, 71:2352-2362.

11. Crapo JD, Hayatdavoudi G, Knapp MJ, Fracica PJ, Wolfe WG, Piantadosi CA: Progressive alveolar septal injury in primates exposed to $60 \%$ oxygen for 14 days. Am J Physiol 1994, 267:L797-L806.

12. Altemeier WA, Sinclair SE: Hyperoxia in the intensive care unit: why more is not always better. Curr Opin Crit Care 2007, 13:73-78.

13. Lodato RF: Decreased O2 consumption and cardiac output during normobaric hyperoxia in conscious dogs. J Appl Physiol 1989, 67:1551-1559.

14. Chan PH: Reactive oxygen radicals in signaling and damage in the ischaemic brain. J Cereb Blood Flow Metab 2001, 21:2-14.

15. Farquhar $H$, Weatherall $M$, Wijesinghe M, Perrin $K$, Ranchord $A$, Simmonds $M$, Beasley R: Systematic review of studies of the effect of hyperoxia on coronary blood flow. Am Heart J 2009, 158:371-377.

16. de Jonge E, Peelen L, Keijzers PJ, Joore H, de Lange D, van der Voort PHJ, Bosman RJ, de Waal RAL, Wesselink R, de Keizer NF: Association between administered oxygen, arterial partial oxygen pressure and mortality in mechanically ventilated intensive care unit patients. Crit Care 2008, 12:R156.

17. Kilgannon JH, Jones AE, Shapiro NI, Angelos MG, Milcarek B, Hunter K, Parrillo JE, Trzeciak $S$ for the Emergency Medicine Shock Research Network (EMShockNet) Investigators: Association between arterial hyperoxia following resuscitation from cardiac arrest and in-hospital mortality. JAMA 2010, 303:2165-2171.

18. Brenner M, Stein D, Hu P, Kufera J, Wooford M, Scalea T: Association between early hyperoxia and worse outcome after traumatic brain injury. Arch Surg 2012, 147:1042-1046.

19. Rincon F, Kang J, Maltenfort M, Vibbert M, Urtecho J, Athar MK, Jallo J, Pineda CC, Tzeng D, McBride W, Bell R: Association between hyperoxia and mortality after stroke: a multicenter cohort study. Crit Care Med 2014, 42:387-396

20. Eastwood G, Bellomo R, Bailey M, Taori G, Pilcher D, Young P, Beasley R: Arterial oxygen tension and mortality in mechanically ventilated patients. Intensive Care Med 2012, 38:91-98.
21. Bellomo R, Bailey M, Eastwood GM, Nichol A, Pilcher D, Hart GK, Reade MC, Egi M, Cooper DJ, the Study of Oxygen in Critical Care (SOCC) group: Arterial hyperoxia and in-hospital mortality after resuscitation from cardiac arrest. Crit Care 2011, 15:R90.

22. Raj R, Bendel S, Reinikainen M, Kivisaari R, Siironen J, Lang M, Skrifvars M: Hyperoxemia and long-term outcome after traumatic brain injury. Crit Care 2013, 17:R177.

23. Young P, Beasly R, Baily M, Bellomo R, Eastwood GM, Nichol A, Pilcher DV, Yunos MN, Egi M, Hart GK, Reade MC, Cooper DJ, for the Study of Oxygen in Critical Care (SOCC) group: The association between early arterial oxygenation and mortality in ventilated patients with acute ischemic stroke. Crit Care Res 2012, 14:14-19.

24. Moher D, Liberati A, Tetzlaff J, Altman DG, The PRISMA Group: Preferred Reporting Items for Systematic Reviews and Meta-Analysis: the PRISMA statement. PLOS Med 2009, 6:e1000097.

25. Downs SH, Black N: The feasibility of creating a checklist for the assessment of the methodological quality both of randomised and non-randomised studies of health care interventions. J Epidemiol Community Health 1998, 52:377-384.

26. Borenstein M, Hedges LV, Higgins JPT, Rothstein HR: Introduction to Meta-Analysis. John Wiley and Sons, Ltd: Chichester, UK; 2009

27. Lipsey MW, Wilson DB (Eds): Practical Meta-Analysis, Volume 49. Thousand Oaks, CA: Sage; 2001

28. Higgins JPT, Thompson SG, Deeks JJ, Altman DG: Measuring inconsistency in meta-analysis. BMJ 2003, 327:557-560.

29. Sterne JAC, Egger M: Funnel plots for detecting bias in meta-analysis: guidelines on choice of axis. J Clin Epidemiol 2001, 54:1046-1055.

30. Kilgannon JH, Jones AE, Parrillo JE, Dellinger RP, Milcarek B, Hunter K, Shapiro NI, Trzeciak S, on behalf of the Emergency Medicine Shock Research Network (EMShockNet) Investigators: Relationship between supranormal oxygen tension and outcome after resuscitation from cardiac arrest. Circulation 2011, 123:2717-2722.

31. Ihle JF, Bernard S, Bailey MJ, Pilcher DV, Smith K, Scheinkestel CD: Hyperoxia in the intensive care unit and outcome after out-of-hospital ventricular fibrillation cardiac arrest. Crit Care Resusc 2013, 15:186-190.

32. Suzuki S, Eastwood GM, Glassford NJ, Peck L, Young H, Garcia-Alvarez M, Schneider AG, Bellomo R: Conservative oxygen therapy in mechanically ventilated patients: a pilot before-and-after trial. Crit Care Med 2014, 42:1414-1422

33. Asher SR, Curry P, Sharma D, Wang J, O'Keefe GE, Daniel-Johnson J, Vavilala MS: Survival advantage and $\mathrm{PaO} 2$ threshold in severe traumatic brain injury. J Neurosurg Anesthesiol 2013, 25:168-173.

34. Davis DP, Meade W, Sise MJ, Kennedy F, Simon F, Tominaga G, Steele J, Coimbra R: Both hypoxemia and extreme hyperoxemia may be detrimental in patients with severe traumatic brain injury. J Neurotrauma 2009, 26:2217-2223.

35. Janz DR, Hollenbeck RD, Pollock JS, McPherson JA, Rice TW: Hyperoxia is associated with increased mortality in patients treated with mild therapeutic hypothermia after sudden cardiac arrest. Crit Care Med 2012, 40:3135-3139.

36. Lee BK, Jeung KW, Lee HY, Lee SJ, Jung YH, Lee WK, Heo T, Min YI: Association between mean arterial blood gas tension and outcome in cardiac arrest patients treated with therapeutic hypothermia. Am J Emerg Med 2014, 32:55-60.

37. Nelskyla A, Parr MJ, Skrifvars MB: Prevalence and factors correlating with hyperoxia exposure following cardiac arrest - an observational single centre study. Scan J Trauma Resusc Emerg Med 2013, 21:35.

38. Rincon F, Kang J, Vibbert M, Urtecho J, Athar MK, Jallo J: Significance of arterial hyperoxia and relationship with case fatality in traumatic brain injury: a multicentre cohort study. J Neurol Neurosurg Psychiatry 2014, 85:799-805

39. Wang $\mathrm{CH}$, Chang WT, Huang CH, Tsai MS, Yu PH, Wang AY, Chen NC, Chen WJ: The effect of hyperoxia on survival following adult cardiac arrest: a systematic review and meta-analysis of observational studies. Resuscitation 2014, 85:1142-1148.

40. Pilcher J, Weatherall M, Shirtcliffe P, Bellomo R, Young P, Beasley R: The effect of hyperoxia following cardiac arrest - A systematic review and meta-analysis of animal trials. Resuscitation 2012, 83:417-422.

41. Kuisma M, Boyd J, Voipio V, Alaspää A, Roine RO, Rosenberg P: Comparison of 30 and the $100 \%$ inspired oxygen concentrations during early post-resuscitation period: a randomized controlled pilot study. Resuscitation 2006, 69:199-206. 
42. Vaahersalo J, Bendel S, Reinikainen M, Kurola J, Tiainen M, Raj R, Pettila V, Varpula T, Skrifvars MB, for the FINNRESUSCI Study Group: Arterial blood gas tensions after resuscitation from out-of-hospital cardiac arrest: associations with long-term neurological outcome. Crit Care Med 2014, 42:1463-1470.

43. Iscoe S, Beasley R, Fisher JA: Supplementary oxygen for non-hypoxemic patients: O2 much of a good thing? Crit Care 2011, 15:305.

44. Li H, Forstermann U: Uncoupling of endothelial NO synthase in atherosclerosis and vascular disease. Curr Opin Pharmacol 2013, 13:161-167.

45. Bourassa MG, Campeau L, Bois MA, Rico O: The effects of inhalation of 100 percent oxygen on myocardial lactate metabolism in coronary heart disease. Am J Cardiol 1969, 24:172-177.

46. Rawles JM, Kenmure AC: Controlled trial of oxygen in uncomplicated myocardial infarction. BMJ 1976, 1:1121-1123.

47. Singhal $A B$, Benner $T$, Roccatagliata L, Koroshetz WJ, Schaefer PW, Lo EH, Buonanno FS, Gonzalez RG, Sorensen AG: A pilot study of normobaric oxygen therapy in acute ischemic stroke. Stroke 2005, 36:797-802

48. Padma MV, Bhasin A, Bhatia R, Garg A, Singh MB, Tripathi M, Prasad K: Normobaric oxygen therapy in acute ischemic stroke: a pilot study in Indian patients. Ann Indian Acad Neurol 2010, 13:284-288.

49. Ronning OM, Guldvog B: Should stroke victims routinely receive supplemental oxygen? A quasi-randomized controlled trial. Stroke 1999, 30:2033-2037.

50. Diringer MN: Hyperoxia - good or bad for the injured brain? Curr Opin Crit Care 2008, 14:167-171.

51. Diringer MN, Aiyagari V, Zazulia AR, Videen TO, Powers WJ: Effect of hyperoxia on cerebral metabolic rate for oxygen measured using positron emission tomography in patients with acute severe head injury. J Neurosurg 2007, 106:526-529.

52. O'Driscoll BR, Howard LS: How to assess the dangers of hyperoxemia: methodological issues. Crit Care 2011, 15:435.

53. Cornet AD, Kooter AJ, Peters MJL, Smulders YM: The potential harm of oxygen therapy in medical emergencies. Crit Care 2013, 17:313.

\section{Submit your next manuscript to BioMed Central and take full advantage of:}

- Convenient online submission

- Thorough peer review

- No space constraints or color figure charges

- Immediate publication on acceptance

- Inclusion in PubMed, CAS, Scopus and Google Scholar

- Research which is freely available for redistribution 